\title{
Reproduction and marine life history of an endemic amphidromous gobiid fish of Reunion Island
}

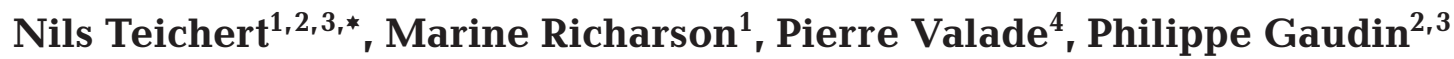 \\ 19RDA, Association Réunionnaise de Développement de l'Aquaculture, Les Sables, BP 16, 97427 Etang Salé, La Réunion \\ ${ }^{2}$ INRA, Institut National de la Recherche Agronomique, UMR 1224 ECOBIOP, Ecologie Comportementale et Biologie des \\ Populations de Poissons, Pôle d'Hydrobiologie de l'INRA, Quartier Ibarron, 64310 St Pée sur Nivelle, France \\ ${ }^{3}$ Univ Pau \& Pays Adour, UMR 1224 ECOBIOP, Ecologie Comportementale et Biologie des Populations de Poissons, \\ UFR Côte Basque, Allée du parc Montaury, 64600 Anglet, France \\ ${ }^{4}$ OCEA Consult' - Organisme Consultant en Environnement Aquatique, BP 22, Centre Régional d'Application Aquacole, \\ 97427 Etang Salé, La Réunion
}

\begin{abstract}
Among amphidromous species, life-history traits of pelagic larvae show high variability between and within species and populations, due to the spatial and temporal variability of the marine environment. Temperature, food availability and seasonal conditions affect survival and larval growth. Among species with an extensive reproduction period, the pelagic conditions encountered by larvae vary according to the hatching date and induce variability in the postlarval and recruitment traits. Post-larvae of the amphidromous goby Cotylopus acutipinnis were collected every new moon between February 2008 and December 2009 at the mouth of a river on Reunion (Mascarene Archipelago, SW Indian Ocean). The relationship between pelagic larval duration (PLD), growth and marine temperature conditions was analysed using the chronological properties of otoliths. C. acutipinnis PLD (mean \pm CI: $108.2 \pm 1.2 \mathrm{~d}$; range: 66 to $164 \mathrm{~d}$ ) and size-atrecruitment (mean \pm CI: $20.5 \pm 0.1 \mathrm{~mm}$; range: 17 to $23 \mathrm{~mm}$ ) varied widely depending on the time of year. Back-calculation of hatching dates showed an extensive spawning season between November and July, which included 2 spawning peaks during the early austral summer and early winter. Summer spawning and high seawater temperature induced faster growth, shorter PLDs and smaller size-at-recruitment compared to early winter reproduction. The significant morphological changes that were demonstrated among amphidromous recruits might influence postrecruitment survival and juvenile settlement in freshwater. Selective mortality may occur according to early life-history traits such as growth patterns, size-at-recruitment and post-larval condition, and should be considered in population management.
\end{abstract}

KEY WORDS: Cotylopus acutipinnis - Amphidromy - Otolith microstructure - Hatching date · Pelagic larval duration $\cdot$ Growth $\cdot$ Seasonal conditions $\cdot$ Sea surface temperature

\section{INTRODUCTION}

Amphidromous life cycles are particularly widespread among freshwater populations of fishes and macro-invertebrates of the Indo-Pacific region (McDowall 1988, 1997, 2007, Keith et al. 2006). Like many marine fishes, amphidromous species have complex life cycles characterised by a pelagic marine growth phase (McDowall 1997, Leis 2002, Hoareau
2005). Spawning and hatching happen in freshwater, and larvae passively drift downstream to the sea immediately after hatching (Bell \& Brown 1995, Iguchi \& Mizuno 1999, Bell 2007, Valade et al. 2009). After 2 to 8 mo as pelagic larvae (Radtke et al. 1988, Hoareau et al. 2007, Lord et al. 2010), individuals return to freshwater at a post-larval stage and then experience a true metamorphosis into juveniles (Keith et al. 2008, Taillebois et al. 2011). 
The pelagic phase plays a fundamental role for amphidromous populations, as it allows larval dispersion and gene flow between fragmented freshwater settlement sites (Berrebi et al. 2005, Keith et al. 2005). Otolithometry (and, to a lesser extent, sclerochronology) is often used to characterise early life history traits of pelagic larvae (Sponaugle 2010). Among marine fishes, the influence of pelagic conditions on growth and size-at-recruitment has been demonstrated in both temperate (Raventos \& Macpherson 2005, Fontes et al. 2011) and tropical waters (McCormick \& Molony 1995, Searcy \& Sponaugle 2000, Bergenius et al. 2005, Sponaugle \& Grorud-Colvert 2006). Among amphidromous species, on the other hand, patterns of marine growth are less known (Shen \& Tzeng 2008, Lord et al. 2010). Their pelagic larval duration (PLD) is longer than that of most marine demersal species (Brothers et al. 1983, Radtke et al. 2001, Hoareau et al. 2007, Lord et al. 2010), and a significant PLD and size-at-recruitment variability has been observed between and within species and, at a larger scale, populations (Bell et al. 1995, Radtke et al. 2001, Hoareau et al. 2007, Maeda \& Yamasaki 2007, Shen \& Tzeng 2008, Lord et al. 2010).

The larval phase is considered the most critical period in the life cycle because of high mortality rates (Anderson 1988, Bell 2007, 2009). Environmental conditions have an important influence on larval fish development, mortality (Cushin 1975) and postsettlement survival (Shima \& Findlay 2002, Hoey \& McCormick 2004, Grorud-Colvert \& Sponaugle 2006, Sponaugle \& Grorud-Colvert 2006, Hamilton 2008). Temperature, food availability and seasonal conditions are often found to influence life history traits and affect recruitment patterns and juvenile mortality (Meekan et al. 2003, Green \& Fisher 2004, Sponaugle \& Pinkard 2004, Sponaugle et al. 2006), explaining the fluctuations in abundance observed in freshwater populations. Understanding these mechanisms and their effects is fundamental when developing management tools, particularly in the case of amphidromous gobies; their post-larvae are indeed subjected to a heavy fishing pressure at the river mouths (Bell 1999). Such an approach is of utmost importance in Reunion, where traditional 'bichiques' fisheries represent a major economic activity for many local fishermen (Delacroix 1987, Delacroix \& Champeau 1992). Fishing pressure affects the stability of fish communities, while heightened mortality of immature fish may result in stock depletion (Bell 1999, Keith et al. 2006, Lord \& Keith 2008, Jenkins et al. 2010).

This study aims to characterise the seasonal variations over 2 consecutive years in pelagic life traits and recruitment of Cotylopus acutipinnis (Guichenot, 1863), an amphidromous goby endemic to the Mascarene islands (Keith et al. 2005, 2006). Post-larval otolith analysis was performed in order to identify the relationships between PLD, size-at-recruitment and marine environmental conditions. A back-calculation of hatching dates was used to (1) identify spawning periods and (2) analyse the influence of the spawning season on marine larval growth.

\section{MATERIALS AND METHODS}

\section{Geographical and biological overview}

Reunion is located in the south-west Indian Ocean, in the western part of the Mascarene Archipelago (Fig. 1). The island is characterised by a wet tropical climate with oceanic influences. Austral winter is a cool, dry season which runs from May to October; austral summer is hot and humid and runs from November to April. Freshwater fish communities of Reunion are mainly composed of diadromous species (Keith et al. 2006). Cotylopus acutipinnis freshwater habitat consists of oligotrophic streams, where individuals feed on benthic algae. Adult sizes range from 4 to $13 \mathrm{~cm}$. This species has been poorly studied (Keith et al. 2005, Hoareau et al. 2007) compared to the widely distributed sympatric species Sicyopterus lagocephalus (Delacroix 1987, Hoareau 2005, Keith et al. 2008, Valade et al. 2009). Cotylopus acutipinnis PLDs range from 78 to 150 d (Hoareau et al. 2007). Very little is known however about its abundance and life history variability at recruitment. As for many marine and amphidromous species, the recruitment phases appear to be linked with the lunar cycle,

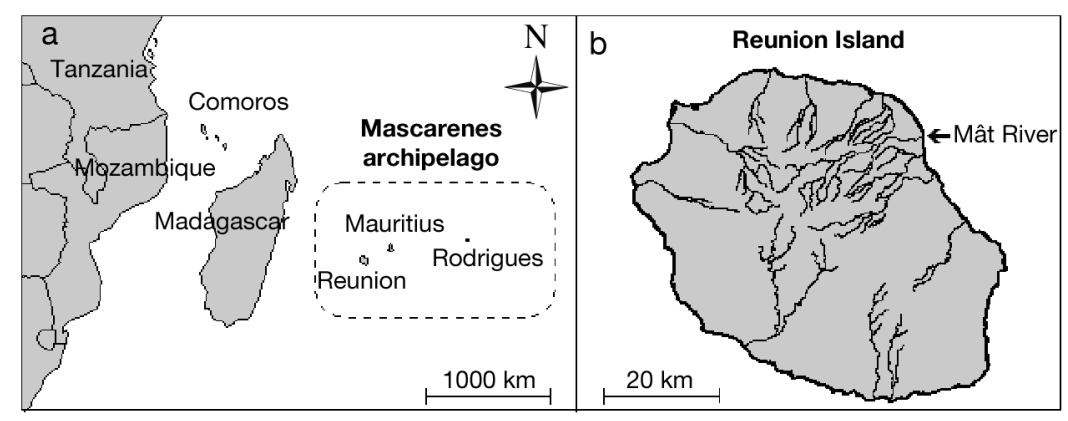

Fig. 1. (a) Reunion Island within the Mascarene Archipelago (south-west Indian Ocean). (b) Sampling site location at the Mât River mouth 
with abundance peaks between the waning halfmoon and the new moon (Bell et al. 1995, Keith 2003, Shen \& Tzeng 2008, Bell 2009).

In this study, the terms 'larval stage' refer to individuals from hatching to recruitment and 'post-larval stage' to individuals at their entrance into freshwater. However, it has to be pointed out that, while allowing clarity, both definitions lack accuracy since postlarval metamorphosis actually starts before the individuals return to freshwater (Keith et al. 2008, Taillebois et al. 2011).

\section{Sampling}

Samples were collected at the mouth of the Mât River, a perennial stream located on the north-eastern side of Reunion (Fig. 1). Sampling was done every new-moon day from February 2008 to December 2009. All post-larvae were caught at the river mouth, just upstream of the salt water limit, using an electrofishing method (DEKA 3000). The $50 \mathrm{~m}^{2}$ sampling area was divided into 5 hydromorphic units, which we defined as presenting both structural and functional uniformity (Pouilly 1994, Malavoi \& Souchon 2002), in particular with regard to water velocity, depth and substratum composition.

The captured post-larvae were anaesthetised with eugenol (clove oil) prior to fixation in 95\% alcohol for specific identification under a binocular microscope. Densities at recruitment were estimated as the number of Cotylopus acutipinnis post-larvae over the sampled area (ind. $\mathrm{m}^{-2}$ ). For both years, the monthly recruitment rate was defined as the density at new moon divided by the total density of recruits during the year.

\section{Otolith analysis}

We randomly selected 30 post-larvae of Cotylopus acutipinnis from 11 samples, from April 2008 to December 2009 ( 1 in every 2 sampling dates). The total length ( $\mathrm{TL} \pm 1 \mathrm{~mm}$ ) of each post-larva was measured. Both sagittal otoliths were extracted under a binocular microscope (Olympus SZ61, X10) and cleaned in 90\% alcohol to remove their thin covering membrane. Since post-larval C. acutipinnis otoliths appear translucent, they did not require any sanding or sectioning in the present study to reveal the growth increments. We assumed that the number of increments was the same within each otolith of a pair, hence only 1 otolith (randomly left or right) per fish was analysed. Otoliths were placed in a drop of immersion oil, observed through a transmitted light microscope (Olympus CX41, X400) and photographed with a microscope camera (Olympus C-5060). Analysis of the photographs was performed with the ImageJ 1.42 software (National Institute of Health, USA).

As in other Sicydiinae (Hoareau et al. 2007, Shen \& Tzeng 2008, Lord et al. 2010), we found a significant linear relationship between otolith size and postlarval size-at-recruitment $(\mathrm{TL}=9.8642+0.0423 \times$ radius, $\left.\mathrm{n}=308, \mathrm{R}^{2}=0.512, \mathrm{p}<0.001\right)$. The width of $\mathrm{a}$ growth increment on an otolith was therefore considered an index of somatic growth and metabolic activity (Campana \& Thorrold 2001). In Sicydiinae postlarvae, otoliths grow in a pattern of successive dark (D-zone) and clear areas (L-zone) on a daily basis (Hoareau et al. 2007, Lord et al. 2010). We counted these growth increments to estimate the age of each post-larva and its hatching day, assuming that the closest increment to the primordium (which we refer to as the first increment) was formed during hatching. The measurements were made from photographs by a single reader along the longest axis starting from the first increment outwards to the edge of the otolith. The distance between every 10 successive increments was measured ( $\mu \mathrm{m} \pm 0.01 \mu \mathrm{m})$ to estimate the average daily growth rate (increment widths, $\mu \mathrm{m} \mathrm{d}^{-1}$ ) and the otolith radius-at-age $(\mu \mathrm{m} \pm 0.01 \mu \mathrm{m})$.

To calculate a spawning activity index, post-larvae were grouped according to both their hatching month and sub-sampling date. A monthly hatching ratio was calculated afterwards for each sub-sampling date, then multiplied by the matching densities at recruitment so as to include an abundance coefficient. Finally, for both years, the monthly reproductive index was defined as the number of larvae hatched per month divided by the total number of larvae hatched during that year. This index was calculated according to the abundance of Cotylopus acutipinnis observed on the sampling dates, assuming a constant larvae survival rate from hatching to recruitment.

\section{Temperature data}

Sea surface temperature (SST) data were obtained from an analysis of NOAA satellite images (http:// coralreefwatch.noaa.gov). The SST product is a twiceweekly composite at 0.5 degree resolution $(\sim 50 \mathrm{~km})$ from nighttime-only data (NOAA Coral Reef Watch 2000). Due to the lack of knowledge of fish behavioural habits at sea and their vertical distribution in the water column, we assumed that the surface temperature was a satisfactory factor for a first approach to the 
relationship between larval traits and environmental conditions. Two average SST $\left({ }^{\circ} \mathrm{C}\right)$ per post-larva were calculated on the Reunion station, France $\left(21^{\circ} 5^{\prime} \mathrm{S}, 55^{\circ}\right.$ E), corresponding to their total pelagic larval period and their first $60 \mathrm{~d}$ after hatching.

\section{Statistical analysis}

Statistical analysis was performed with open source R software (R Development Core Team 2010). Size-atrecruitment, PLD and otolith radius-at-age means are given with confidence intervals (CI). Age and otolith size measurements were log-transformed to better meet the assumption of normality required for ANOVA and multivariate analysis of covariance (MANCOVA). The critical level of significance was $\alpha=0.05$ for all analyses. The relationship between PLD and size-at-recruitment was analysed using linear regression (F-test). ANOVAs with fixed factors were used to test the sampling date effect $(n=11)$ on size-at-recruitment and PLD. Differences in PLD and size-at-recruitment between hatching years (2008 and 2009) and hatching season (summer and winter) were tested using 2-way ANOVAs. The relationships between the otolith radius-at-age (proxy of growth), PLD and abundance at recruitment were examined using Pearson's correlation tests (r) for all ages considered separately.

A repeated-measures MANCOVA was used to test the influence of hatching year (2008 and 2009), hatching season (summer and winter) and average 0 to $60 \mathrm{~d}$ temperature (SST) on otolith radius for each $10 \mathrm{~d}$ period from hatching to $60 \mathrm{~d}$. This interval was chosen because it met the requirement of equality in the number of individuals for each age group. After $60 \mathrm{~d}$, some post-larvae had already recruited and the number of individuals had decreased. Wilks' lambda statistics were used for the tests. Subsequent to MANCOVA, univariate $F$-tests were conducted in order to ascertain the significant $10 \mathrm{~d}$ period for each tested factor on otolith radius. To examine the relationships between PLD, size-at-recruitment and average temperature during the pelagic phase, we performed Pearson's correlation tests (r).

\section{RESULTS}

During this study, 4699 Cotylopus acutipinnis postlarvae were caught (2410 in February to December 2008 and 2289 in January to December 2009). A total of 308 otoliths were analysed from April 2008 to
December 2009 samples (30 post-larvae per subsampling date, except on 2 dates: August 2008, n = 28; December 2008, $\mathrm{n}=10$ ).

\section{Variability of PLD and size at recruitment}

The PLD determined from the otolith analysis was $108.2 \pm 1.2 \mathrm{~d}$ (range: 66 to $164 \mathrm{~d}$ ), resulting in a TL of $20.5 \pm 0.1 \mathrm{~mm}$ (range: 17 to $23 \mathrm{~mm}$ ). Significant variations in average PLD (ANOVA, $\mathrm{n}=308, F_{10,297}$ $=60.3, \mathrm{p}<0.001)$ and TL $\left(\right.$ ANOVA, $\mathrm{n}=308, F_{10,297}=$ $25.71, \mathrm{p}<0.001)$ were observed among sampling

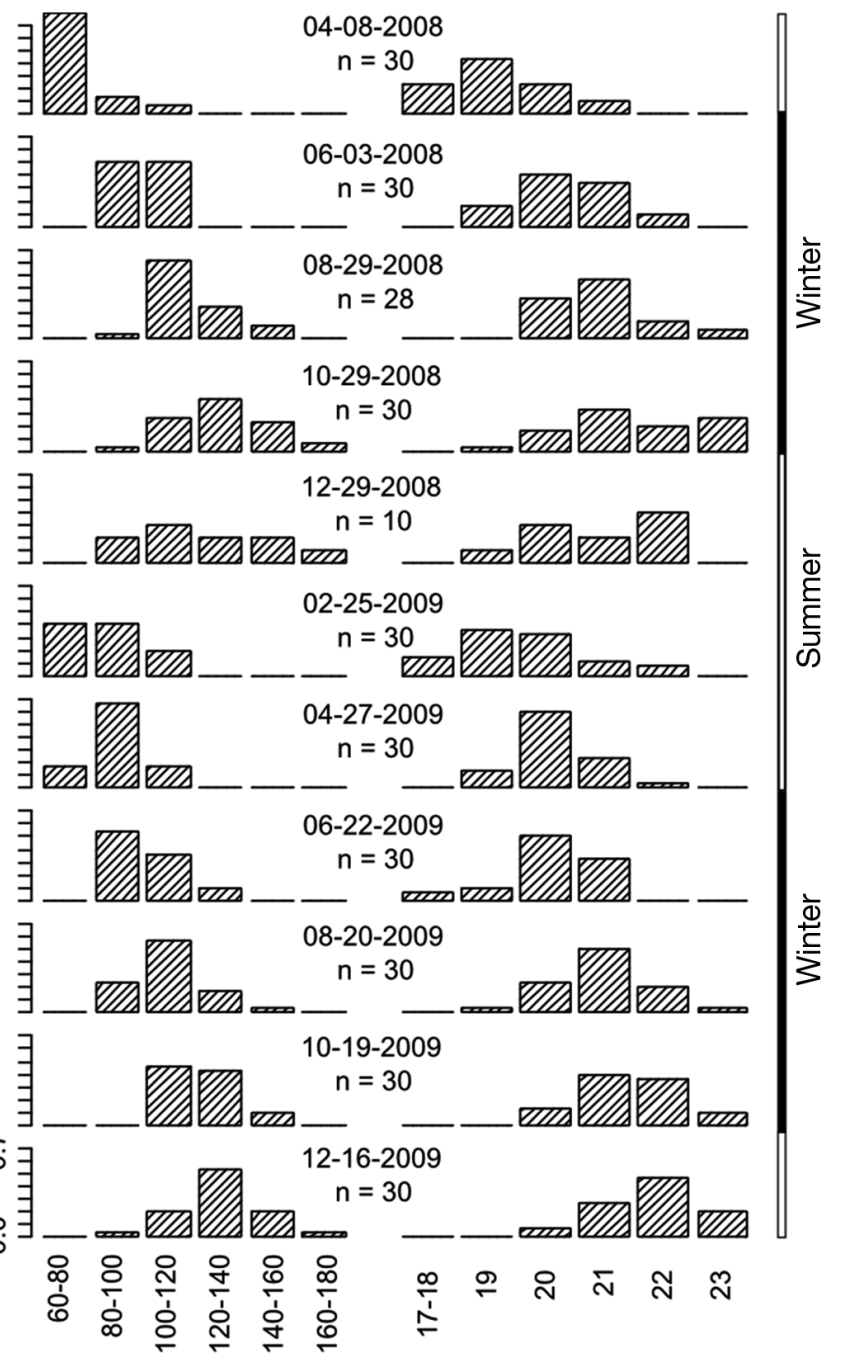

Pelagic larval duration (d) Size-at-recruitment (mm)

Fig. 2. Cotylopus acutipinnis. Pelagic larval duration and size-at-recruitment distributions of the post-larvae collected at the Mât River mouth, according to sampling date, from April 2008 to December 2009. Dates are given as mm-dd-yyyy, $\mathrm{n}=$ sample size 


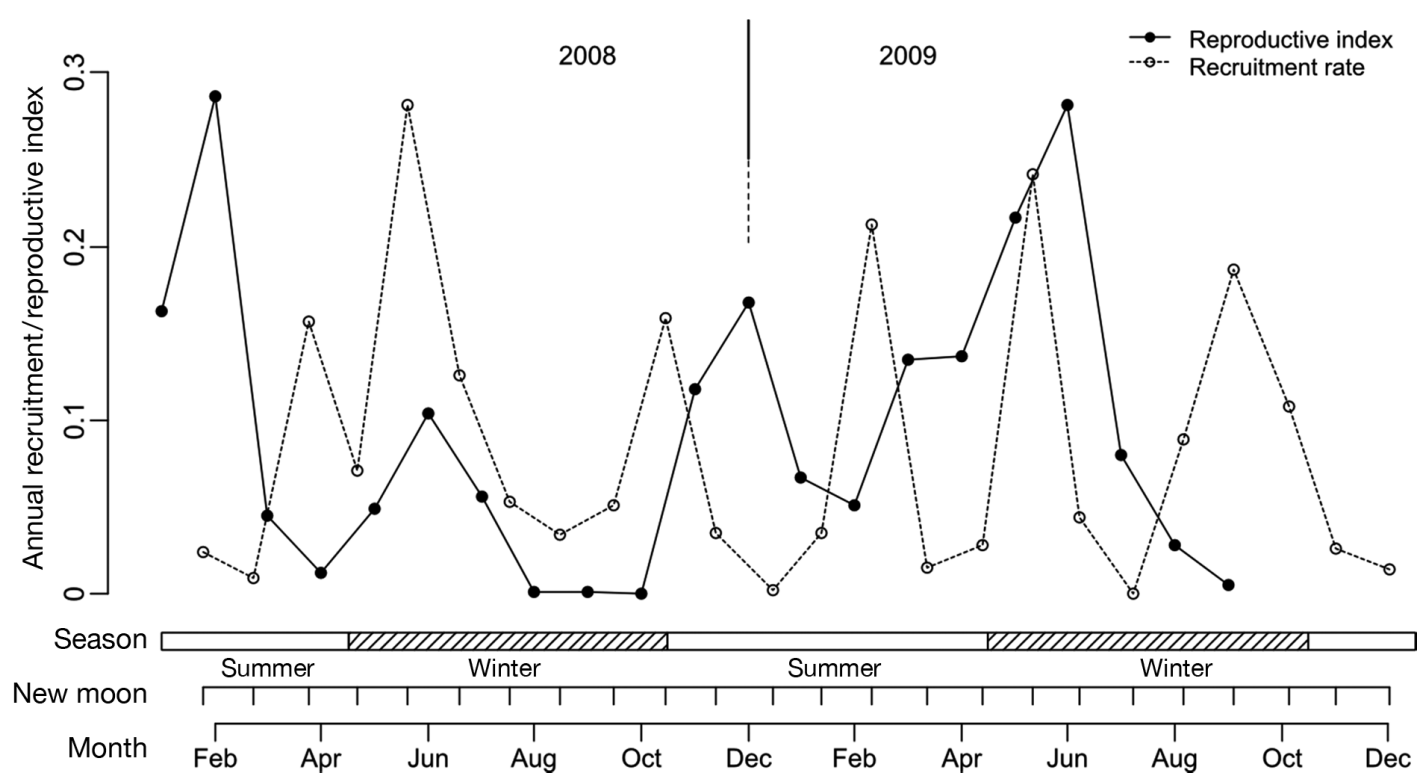

Fig. 3. Cotylopus acutipinnis. Recruitment and annual reproductive indexes calculated from post-larvae collected at the Mât River mouth in 2008 to 2009. The reproductive rate was determined on a monthly basis using back-calculation of hatching dates. The observed abundance ratio on the sampling date was used to correct it

dates (Fig. 2). Smaller individuals were observed in April 2008 (19.1 $\pm 0.2 \mathrm{~mm})$ and February 2009 (19.3 $\pm 0.2 \mathrm{~mm}$ ) and these had shorter PLDs $(79 \pm 2$ and $87 \pm 3 d$, respectively, for April and February). The biggest individuals were observed in October 2008 $(21.4 \pm 0.2 \mathrm{~mm})$ and December $2009(21.8 \pm 0.2 \mathrm{~mm})$ and these had longer PLDs $(133 \pm 3$ and $130 \pm 3 \mathrm{~d}$, respectively, for October and December). Postlarvae which spent more time at sea (longer PLD) were larger at recruitment $(\mathrm{TL}=-0.094+4.429 \times$ $\left.\log (\mathrm{PLD}), \mathrm{R}^{2}=0.55, \mathrm{p}<0.001\right)$ and recruited in late winter or early summer (October and December).

\section{Abundance at recruitment and spawning season}

Abundance at recruitment varied widely throughout the year (Fig. 3). Two prominent abundance periods could be identified in February to June (late summer to early winter) and September to October (late winter). Hatching date back-calculation from otolith analysis was used to estimate the monthly reproductive index. The annual reproductive activity was bimodal, showing 2 spawning peaks (Fig. 3). The first one took place during the first half of summer (November to February) and the second during early winter (May to June). The cold period in the second half of winter (August to October) was marked by a pause in the spawning activity (February to April), during which no larvae hatched.

\section{PLD and size-at-recruitment variability and influ- ence of the spawning season}

The back-calculation of hatching days of the postlarvae allowed the examination of the relationship between hatching season, PLD and size-at-recruitment (Fig. 4). The post-larvae that hatched during the first year of study (TL $=20.2 \pm 0.1 \mathrm{~mm}$ and PLD $=$ $105 \pm 2$ d) were significantly smaller (2-way ANOVA, $\left.\mathrm{n}=308, F_{1,304}=28.59, \mathrm{p}<0.001\right)$ and younger $(2-$ way ANOVA, $\mathrm{n}=308, F_{1,304}=14.22, \mathrm{p}<0.001$ ) than those hatched during the second year $(\mathrm{TL}=20.9 \pm$ $0.1 \mathrm{~mm}$ and PLD $=111 \pm 2 \mathrm{~d}$ ). Interaction between year and season was significant for PLD analysis, showing that the PLD variations between seasons were different for the 2 studied years (2-way ANOVA, $\left.\mathrm{n}=308, F_{1,304}=8.69, \mathrm{p}=0.003\right)$. Despite this variability across the study year and season, the winterhatched post-larvae showed significantly larger sizeat-recruitment $(21.2 \pm 0.1 \mathrm{~mm} ; 2$-way ANOVA, $\mathrm{n}=$ $\left.308, F_{1,304}=89.05, \mathrm{p}<0.001\right)$ and a longer PLD $(123 \pm$ $1.5 \mathrm{~d}$; 2-way ANOVA, $\mathrm{n}=308, F_{1,304}=163.03, \mathrm{p}<$ 0.001 ) than those hatched in summer (TL $=20 \pm$ $0.1 \mathrm{~mm}$ and PLD $=97 \pm 1.3 \mathrm{~d}$ ).

\section{Marine growth}

Otolith growth rates were not linear. They rapidly increased during the first $20 \mathrm{~d}$, gradually decreased over the next $90 \mathrm{~d}$, and then were almost constant 


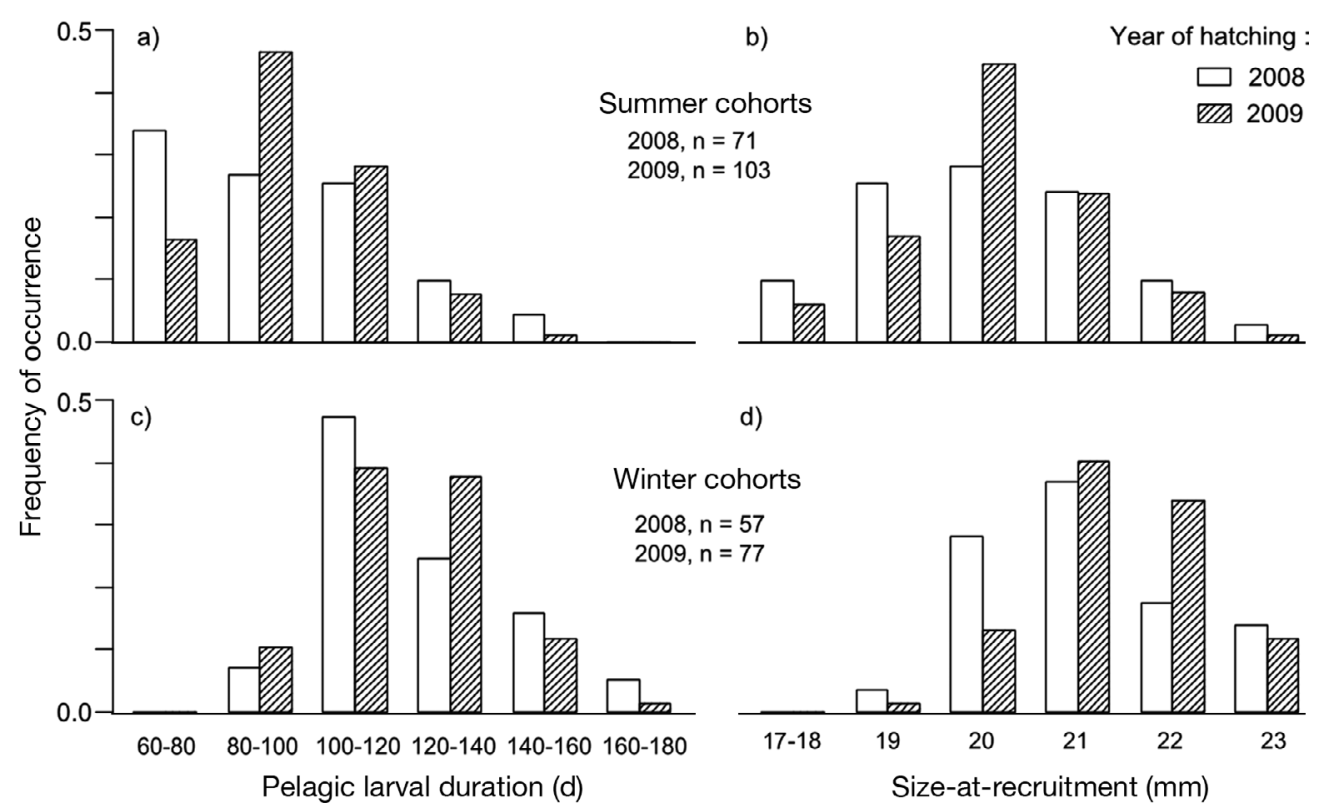

Fig. 4. Cotylopus acutipinnis. Seasonal distributions of the $(a, c)$ pelagic larval duration and $(b, d)$ size-at-recruitment of $(a, b)$ summer-hatched and $(\mathrm{c}, \mathrm{d})$ winter-hatched post-larvae, according to the hatching year. $\mathrm{n}=$ sample size

until recruitment (Fig. 5). This pattern has also been observed in both pelagic coral reef (Bergenius et al. 2002, Vigliola \& Meekan 2002) and amphidromous species (Lord et al. 2010). The PLD was significantly correlated with otolith size for all ages during the marine phase (Fig. 6). The correlation coefficient gradually increased and was highest at 60 to $70 \mathrm{~d}$, which corresponded to the first post-larval recruitment. Thus post-larvae showing a fast marine growth recruited at a younger age than slowly grown larvae.

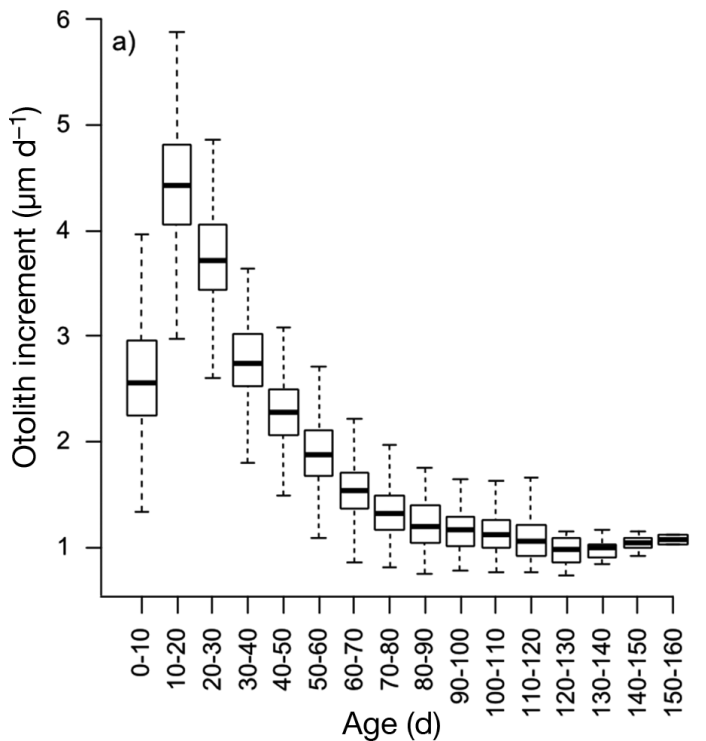

There was no significant correlation between abundance at recruitment and PLD or otolith size for all ages $(p>0.05)$.

The repeated-measures MANCOVA showed that the otolith radius-at-age significantly differed between years and seasons from 0 to $60 \mathrm{~d}$ (Table 1a). The otolith sizes of fish sampled during the first year were larger at the same age than those collected during the second year. Significant interaction between temperature and season led us to split the repeated-

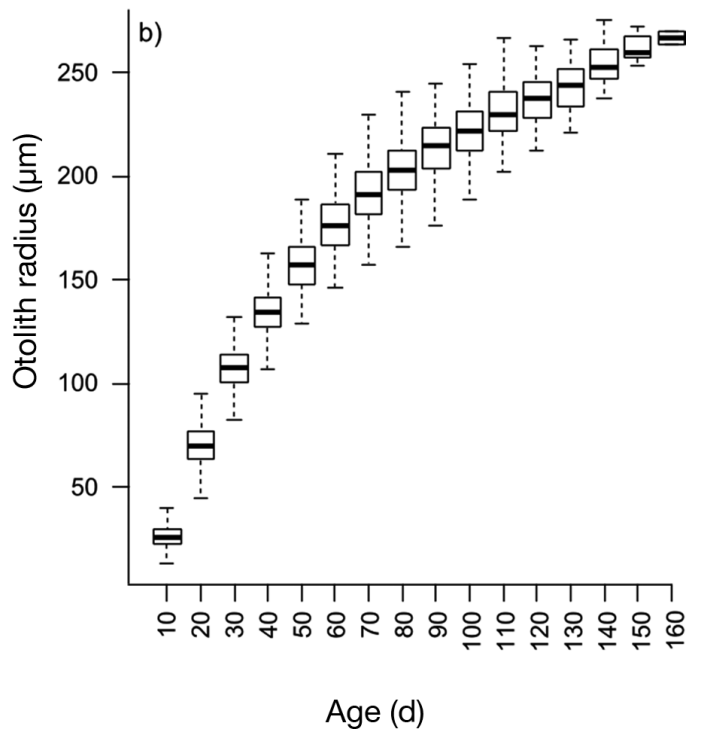

Fig. 5. Cotylopus acutipinnis. (a) Otolith increment widths (proxy for somatic growth) calculated in $10 \mathrm{~d}$ increments during the marine phase and (b) otolith radius-at-age (proxy for size) of the marine larvae. Box-plots illustrate the smallest and largest observation (whiskers), lower and upper quartiles (boxes) and median (horizontal bar) 


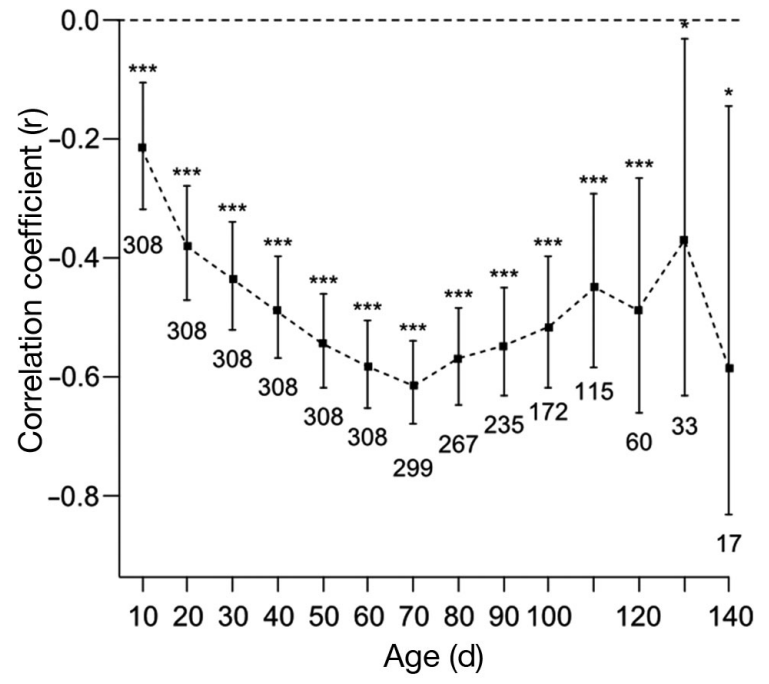

Fig. 6. Cotylopus acutipinnis. Pearson's correlation coefficients (r) between pelagic larval duration (PLD) and otolith radius-at-age for every $10 \mathrm{~d}$ period after hatching. Bars $=\mathrm{CI}$ at $95 \%$. The number of otoliths used in the correlation test is specified. ${ }^{* * *} \mathrm{p}<0.001,{ }^{*} \mathrm{p}<0.05$

measures MANCOVA according to the sampling year, in order to test and explain their main effect and interaction (Table $1 \mathrm{~b}$ ). At the same age, the average otolith sizes of summer hatchlings were larger than those of the winter ones (Fig. 7). The average SST in summer was $27.70^{\circ} \mathrm{C}$ (range: 25.09 to $28.80^{\circ} \mathrm{C}$ ) and
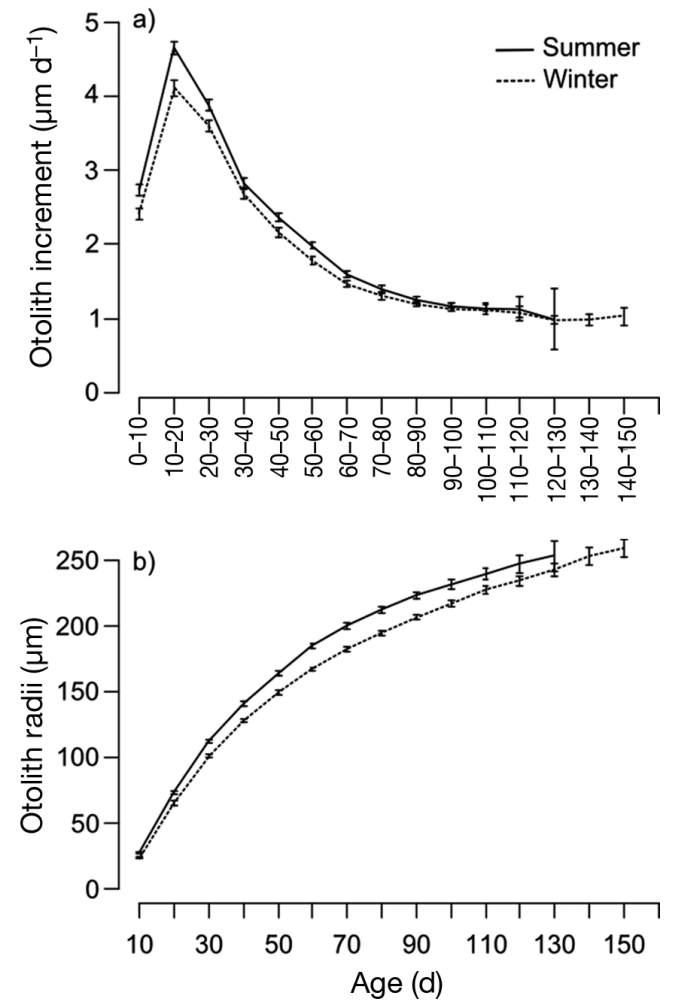

Fig. 7. Cotylopus acutipinnis. Mean $\pm 95 \%$ CI (a) otolith increment width (proxy for somatic growth) and (b) otolith radius-at-age (proxy for size) during the pelagic phase of postlarvae sampled in the Mât River from 2008 to 2009, according to their hatching season
Table 1. Cotylopus acutipinnis. (a) Summary of the repeated-measures MANCOVA results which tested the hatching year (2008 and 2009), hatching season (summer and winter) and average sea surface temperature (SST, 0 to $60 \mathrm{~d}$ ) effect on otolith radius-at-age from hatching to $60 \mathrm{~d}$. (b) Summary of the repeated-measures MANCOVA results of otolith radius-at-age split according to sampling year. Tested factors were hatching season (summer and winter) and average SST (0 to $60 \mathrm{~d}$ ). Bold: significant values $(\mathrm{p}<0.05)$

\begin{tabular}{|lrrrrc|}
\hline Factor & Wilks' $\lambda$ & $F$ & Effect df & Error df & $\mathrm{p}$ \\
\hline a) & & & & & \\
Year & 0.87 & 7.56 & 6 & 295 & $<\mathbf{0 . 0 0 1}$ \\
Season & 0.58 & 35.74 & 6 & 295 & $<\mathbf{0 . 0 0 1}$ \\
SST & 0.79 & 13.03 & 6 & 295 & $<\mathbf{0 . 0 0 1}$ \\
Year $\times$ Season & 1.00 & 0.01 & 6 & 295 & 0.99 \\
Year $\times$ SST & 0.97 & 1.51 & 6 & 295 & 0.18 \\
Season $\times$ SST & 0.92 & 4.00 & 6 & 295 & $<\mathbf{0 . 0 0 1}$ \\
Triple interaction & 0.97 & 1.69 & 6 & 295 & 0.12 \\
b) & & & & & \\
2008 & & & & & \\
Season & 0.49 & 25.53 & 6 & 150 & $<\mathbf{0 . 0 0 1}$ \\
SST & 0.78 & 7.10 & 6 & 150 & $<\mathbf{0 . 0 0 1}$ \\
Season $\times$ SST & 0.87 & 3.77 & 6 & 150 & $\mathbf{0 . 0 0 1}$ \\
2009 & & & & & \\
Season & 0.65 & 12.52 & 6 & 140 & $<\mathbf{0 . 0 0 1}$ \\
Temperature & 0.76 & 7.21 & 6 & 140 & $<\mathbf{0 . 0 0 1}$ \\
Season $\times$ SST & 0.92 & 2.03 & 6 & 140 & 0.07 \\
\hline
\end{tabular}

$24.31^{\circ} \mathrm{C}$ in winter (range: 22.88 to $26.13^{\circ} \mathrm{C}$ ) over the 2 studied years. The average temperature encountered by larvae between 0 and $60 \mathrm{~d}$ had a significant, positive effect on otolith radius-atage for both studied years (Table $1 \mathrm{~b}$ ). A significant effect of the temperature $\times$ season interaction was only observed in 2008, showing a lower influence of temperature augmentation on otolith radius in winter than in summer. Univariate $F$-tests showed that the 3 tested factors had significant main effects on otolith size for all ages between 0 and $60 \mathrm{~d}(\mathrm{p}<0.001)$. The interaction between temperature and season was only significant for ages between 40 and $60 \mathrm{~d}(\mathrm{p}<0.001)$.

PLD and size-at-recruitment (TL) were negatively correlated with the average temperature encountered by larvae during their pelagic period (SST vs. PLD: $\mathrm{r}=-0.57, \mathrm{p}<0.001$; SST vs. TL: $\mathrm{r}=-0.44, \mathrm{p}<0.001)$. Overall, summerspawning cohorts encountered warmer temperatures during their pelagic phase and had smaller sizes-at-recruitment and shorter PLDs than winter-spawning cohorts. 


\section{DISCUSSION}

\section{PLD and endemism of Cotylopus acutipinnis}

The marine phase of amphidromous species plays a fundamental role in population function (Bonhomme \& Planes 2000, Hoareau 2005). It allows larval dispersion and inter-river population mixing throughout the distribution area (Berrebi et al. 2005, Keith et al. 2005). Amphidromous species show longer PLDs ( $\sim 70$ to $300 \mathrm{~d})$ than marine demersal species (<60 d) (Brothers et al. 1983, Radtke et al. 2001, Keith 2003, Hoareau 2005). Lord et al. (2010) assumed that long PLDs were fostered by a higher fragmentation of insular freshwater systems compared with coral reef systems, given that reaching the settlement sites in the former requires more time. In addition, among amphidromous species, long PLDs coincide with wide geographic distributions (Keith et al. 2005, McDowall 2008, Lord et al. 2010). The PLD of Cotylopus acutipinnis is relatively short compared to other amphidromous species $(108 \pm 1.2 \mathrm{~d})$. For example, it is twice as short as that of Sicyopterus lagocephalus, a sympatric Sicydiinae in Reunion which is widely distributed throughout the Indo-Pacific region (Hoareau et al. 2007). A short PLD trait appears consistent with short-distance dispersion, as has been observed among other endemic amphidromous fishes (Lord et al. 2010). However, most reef fishes show shorter PLDs than C. acutipinnis and are still widely distributed (Victor \& Wellington 2000). PLD variation is probably one of many factors influencing a species' distribution, which results from complex interactions between local environment (i.e. currents, oceanography, temperature, etc.) and biological traits (PLD, larval behaviour, etc.).

\section{Reproductive strategy}

Many gobies have annual reproductive cycles (Ha \& Kinzie 1996, Keith 2003, McDowall 2004, 2007). We have shown that the spawning season of Cotylopus acutipinnis extends over the major part of the year, with a pause between August and October. This broad time range has also been observed in Reunion for Sicyopterus lagocephalus. For the latter, duration of the spawning period appears to be mainly related to both water temperature and altitude (ARDA unpubl. data). Multiple spawning has been demonstrated for other amphidromous gobies (Rhinogobius sp.), among which the largest individuals are able to spawn up to 3 times per reproductive season
(Tamada \& Iwata 2005, Shimizu et al. 2005, 2008). For C. acutipinnis, our results showed 2 peaks of spawning activity in each reproductive period, suggesting a biannual spawning. The first peak appeared in early austral summer (November to February) and the second in early winter (May to June). The spawning activity paused during the second half of winter (August to October), which is the coldest period of the year. However, we calculated the spawning activity index assuming a constant survival rate from hatching to recruitment; differential survival rates during the marine larval phase might explain the observed bimodal shape as well. Summer-hatched pelagic larvae might indeed be subjected to a higher mortality because of predation, starvation, or ocean currents for instance. This would show a subsequent lower abundance at recruitment and a drop in the index for the related period. Future studies on sexual maturation and reproduction patterns in rivers would (1) provide a better description and understanding of the reproductive strategies of C. acutipinnis and (2) test whether the assumption of a uniform larval mortality over the year is supported, should the pattern of reproduction be similar to the one observed herein.

\section{Marine larval growth and dynamics of post-larval recruitment}

Pelagic larval marine growth rate is probably influenced by several seasonal factors (Bell et al. 1995, Searcy \& Sponaugle 2000, Shen \& Tzeng 2008). Temperature has often been shown to directly influence the growth rate of marine larvae (McCormick \& Molony 1995, Meekan et al. 2003, Green \& Fisher 2004, Jenkins \& King 2006, Sponaugle et al. 2006), these showing greater growth rates in warm waters than in cool ones (Sponaugle \& Grorud-Colvert 2006, Sponaugle et al. 2006). Other seasonal factors can also significantly influence growth rates: food availability (Searcy \& Sponaugle 2000, Meekan et al. 2003), solar radiation, rainfall, wind (Bergenius et al. 2005) and salinity (Bergenius et al. 2002). These factors, taken individually or altogether, vary over time (Bergenius et al. 2005) and affect pelagic larval growth accordingly. We did observe greater growth rates among summer-hatched pelagic Cotylopus acutipinnis larvae than winter-hatched ones. In this case, both temperature and variations in marine environmental conditions may have significantly contributed to this seasonal effect, similarly to what has been observed for reef species (Sponaugle \& Pinkard 2004, Bergenius et al. 2005). 
Seasonal variations in pelagic larval growth rates and recruitment dynamics have been demonstrated for some marine demersal (Searcy \& Sponaugle 2000, Bergenius et al. 2002, 2005) and amphidromous species (Bell et al. 1995, Shen \& Tzeng 2008). High growth rates increase survival chances during the pelagic larval phase (Bergenius et al. 2002, 2005, Fontes et al. 2011). Jenkins \& King (2006) showed that a temperature augmentation in the vicinity of spawning grounds enhanced both larval growth rates and post-larval survival of Sillaginodes punctata.

Anderson (1988) based his 'growth-mortality' hypothesis on 2 theories. The first concept is 'bigger is better': it states that larger individuals are less vulnerable to predation than smaller individuals at the same age (Miller et al. 1988). The second one is the 'stage-duration' assumption which predicts that survival is greater for individuals with shorter PLDs since this limits their vulnerability period (i.e. to predation or starvation) (Leggett \& Deblois 1994). Bell et al. (1995) showed that peaks of abundance-atrecruitment were consistent with faster pelagic growth and shorter PLDs in 2 Sicydiinae species. In the case of Cotylopus acutipinnis however, no correlations were found between growth rate and abundance-atrecruitment. This may be explained by a bias in our estimation of densities-at-recruitment: among Sicydiinae, large aggregations of post-larvae are commonly observed onshore prior to recruitment (Delacroix \& Champeau 1992, Keith 2003). Abundance in new recruits might, therefore, differ from one river mouth to another depending on the day (ARDA unpubl. data). However, although sampling was conducted at a single site, we assumed that, since small distances separate the rivers mouths in Reunion, distribution of early life history traits (PLD, TL, growth pattern) would be similar among recruitment sites. A single sampling site could have been insufficient to reflect the abundance at recruitment at the island scale.

\section{Marine life and post-larval characteristics}

At recruitment, size and fitness of post-larvae are linked to pelagic growth patterns (Searcy \& Sponaugle 2000, Hamilton 2008). Contrary to observations made by Hoareau et al. (2007), we showed that for Cotylopus acutipinnis, PLD varied significantly between months and was positively correlated with the post-larval size-at-recruitment. PLD increased throughout the year and ranged by a factor of 2.5 (66 to 164 d). Variations in both PLD and size-at- recruitment were closely related to the hatching period and marine conditions, and inversely correlated to marine growth. This relationship between slower growth, longer marine phases and larger sizes-at-recruitment has been observed among numerous reef post-larvae (Searcy \& Sponaugle 2000, Shima \& Findlay 2002, Sponaugle \& Pinkard 2004, Bergenius et al. 2005, Grorud-Colvert \& Sponaugle 2006) and amphidromous fishes (Shen \& Tzeng 2008).

For several marine species, post-recruitment survival and successful juvenile settlement depend on both the pelagic environmental conditions and the recruits' characteristics (Shima \& Findlay 2002, Vigliola \& Meekan 2002, Hoey \& McCormick 2004, Raventos \& Macpherson 2005, Sponaugle \& GrorudColvert 2006). For instance, Gagliano \& McCormick (2007) demonstrated that successful juvenile settlement of Pomacentrus amboinensis on the reef depended on their size-at-recruitment. Other studies have shown that size-at-recruitment is not decisive; however, individual body condition is of primary importance (Hoey \& McCormick 2004, Grorud-Colvert \& Sponaugle 2006). For Thalassoma bifasciatum, rapidly grown larvae show better condition and higher lipid reserve at recruitment than slowly grown ones (Searcy \& Sponaugle 2000, Sponaugle \& GrorudColvert 2006, Hamilton 2008).

It appears, however, that the influence of these factors on survival and settlement of recruits might vary over time and space, because of environmental variations, predation, or competition (Sponaugle \& Grorud-Colvert 2006). In the first place, we showed in our study of Cotylopus acutipinnis that the extensive spawning period led to a considerable variability in larval traits depending on the spawning cohort: PLD and size-at-recruitment were shorter for summer-hatching (first spawning peak) than for winterhatching cohorts (second spawning peak). This large variability in early life history patterns might influence juvenile survival (Vigliola \& Meekan 2002, Raventos \& Macpherson 2005). Furthermore, adult amphidromous gobies are generally territorial (Keith 2003); therefore, the massive recruitment of postlarvae occurring in Reunion (Delacroix \& Champeau 1992, Bell 1999) may result in intense competition for river habitat, where adult populations already dwell (Keith 2003, Keith et al. 2008). Lastly, a successful post-larval recruitment is energetically costly. After entering freshwater, the body condition of Sicyopterus lagocephalus post-larvae decreases progressively due to their metamorphosis and a prior nonfeeding week (Taillebois et al. 2011). As a consequence, a better condition at recruitment (e.g. high 
lipid and protein contents) and a faster early juvenile growth might enhance survival of juvenile fishes (Searcy \& Sponaugle 2000, 2001, Sponaugle \& Grorud-Colvert 2006). Therefore, it is plausible that, as in other fish species, only a fraction of the total $C$. acutipinnis spawn contribute to the adult population, depending on the hatching date and environmental conditions later encountered by larvae (Sponaugle 2010). Multiple spawning events combined with high fecundity during the reproductive season could be an adaptive parental strategy to enhance the survival chances of larvae and post-larvae in response to the marine environmental variations and stochasticity.

To conclude, it is now necessary to complete this work with an in situ study of Cotylopus acutipinnis reproduction so as to validate their spawning strategy and characterise their marine survival variability. Both of these parameters are needed in order to develop population models which are necessary for species management and conservation.

Acknowledgements. We are thankful to the personnel of ARDA for their help and commitment: P. Bosc (director) and H. Grondin (technician). We also thank S. Descloux (EDF) and the 4 reviewers for their helpful comments and suggestions which helped us improve this manuscript. Sample collection was conducted during the 'Observation of diadromous species migrations in Reunion' program, directed by the ARDA (Association Réunionnaise de Développement de l'Aquaculture). The present study was conducted with the financial support of Electricite De France (22-30 avenue de Wagram, 75382 Paris Cedex 8), the Office de l'Eau Réunion (49 rue Mazagran, 97400 Saint Denis), the Région Réunion (Avenue René Cassin, BP 7190, 97719 Saint Denis Cedex 9), the Direction de l'Environnement, de l'Aménagement et du Logement (2 rue Juliette Dodu, 97706 Saint Denis Messag Cedex 9), Parc national de La Réunion (112 rue Sainte Marie, 97400 St Denis) and the European Union (FEDER and European Social Fund).

\section{LITERATURE CITED}

Anderson JT (1988) A review of size-dependent survival during pre-recruit stages of fishes in relation to recruitment. J Northwest Atl Fish Sci 8:55-66

Bell KNI (1999) An overview of goby-fry fisheries. Naga 22: 30-36

Bell KNI (2007) Opportunities in stream drift: methods, goby larval types, temporal cycles, in situ mortality estimation, and conservation implications. In: Evenhuis NL, Fitzsimons JM (eds) Biology of Hawaiian streams and estuaries. Bishop Museum Bulletin in Cultural and Environmental Studies 3:35-61

Bell KNI (2009) What comes down must go up: The migration cycle of juvenile-return anadromous taxa. Am Fish Soc Symp 69:321-341

Bell KNI, Brown JA (1995) Active salinity choice and enhanced swimming endurance in 0 to 8-d-old larvae of diadromous gobies, including Sicydium punctatum (Pisces), in Dominica, West Indies. Mar Biol 121:409-417

Bell KNI, Pepin P, Brown JA (1995) Seasonal, inverse cycling of length and age-at-recruitment in the diadromous gobies Sicydium punctatum and Sicydium antillarum in Dominica, West-Indies. Can J Fish Aquat Sci 52: 1535-1545

Bergenius MAJ, Meekan MG, Robertson DR, McCormick MI (2002) Larval growth predicts the recruitment success of a coral reef fish. Oecologia 131:521-525

Bergenius MAJ, McCormick MI, Meekan MG, Robertson DR (2005) Environmental influences on larval duration, growth and magnitude of settlement of a coral reef fish. Mar Biol 147:291-300

> Berrebi P, Cattaneo-Berrebi G, Valade P, Ricou JF, Hoareau $\mathrm{T}$ (2005) Genetic homogeneity in eight freshwater populations of Sicyopterus lagocephalus, an amphidromous gobiid of La Réunion Island. Mar Biol 148:179-188

Bonhomme F, Planes S (2000) Some evolutionary arguments about what maintains the pelagic interval in reef fishes. Environ Biol Fishes 59:365-383

Brothers ES, Williams D, Sale PF (1983) Length of larval life in twelve families of fish at 'One Tree Lagoon', Great Barrier Reef, Australia. Mar Biol 76:319-324

$>$ Campana SE, Thorrold SR (2001) Otoliths, increments, and elements: keys to a comprehensive understanding of fish populations? Can J Fish Aquat Sci 58:30-38

Cushin DH (1975) Marine ecology and fisheries. Cambridge University Press, Cambridge

Delacroix P (1987) Étude des «Bichiques», juvéniles de Sicyopterus lagocephalus (Pallas), poisson gobiidae migrateur des rivières de la Réunion (Océan Indien): Exploitation, répartition, biologie de la reproduction et de la croissance. PhD thesis, University of La Réunion

$>$ Delacroix P, Champeau A (1992) Ponte en eau douce de Sicyopterus lagocephalus (Pallas) poisson Gobiidae amphibionte des rivières de la Réunion. Hydroécol Appl $4: 49-63$

Fontes J, Santos RS, Afonso P, Caselle JE (2011) Larval growth, size, stage duration and recruitment success of a temperate reef fish. J Sea Res 65:1-7

> Gagliano M, McCormick MI (2007) Compensating in the wild: is flexible growth the key to early juvenile survival? Oikos 116:111-120

> Green BS, Fisher R (2004) Temperature influences swimming speed, growth and larval duration in coral reef fish larvae. J Exp Mar Biol Ecol 299:115-132

> Grorud-Colvert K, Sponaugle S (2006) Influence of condition on behavior and survival potential of a newly settled coral reef fish, the bluehead wrasse Thalassoma bifasciatum. Mar Ecol Prog Ser 327:279-288

> Ha PY, Kinzie RA (1996) Reproductive biology of Awaous guamensis, an amphidromous Hawaiian goby. Environ Biol Fishes 45:383-396

Hamilton SL (2008) Larval history influences postmetamorphic condition in a coral-reef fish. Oecologia 158:449-461

Hoareau T (2005) Dynamique structurale des populations de bichiques (Sicyopterus lagocephalus), Gobiidae amphidromes des rivières de La Réunion. PhD thesis, University of La Réunion

- Hoareau T, Lecomte-Finiger R, Grondin HP, Conand C, Berrebi P (2007) Oceanic larval life of La Réunion 'bichiques', amphidromous gobiid post-larvae. Mar Ecol Prog Ser 333:303-308 
Hoey AS, McCormick MI (2004) Selective predation for low body condition at the larval-juvenile transition of a coral reef fish. Oecologia 139:23-29

Iguchi K, Mizuno N (1999) Early starvation limits survival in amphidromous fishes. J Fish Biol 54:705-712

Jenkins GP, King D (2006) Variation in larval growth can predict the recruitment of a temperate, seagrassassociated fish. Oecologia 147:641-649

Jenkins AP, Jupiter SD, Qauqau I, Atherton J (2010) The importance of ecosystem-based management for conserving aquatic migratory pathways on tropical high islands: a case study from Fiji. Aquat Conserv: Mar Freshw Ecosyst 20:224-238

Keith P (2003) Biology and ecology of amphidromous Gobiidae of the Indo-Pacific and the Caribbean regions. J Fish Biol 63:831-847

Keith P, Galewski T, Cattaneo-Berrebi G, Hoareau T, Berrebi P (2005) Ubiquity of Sicyopterus lagocephalus (Teleostei: Gobioidei) and phylogeography of the genus Sicyopterus in the Indo-Pacific area inferred from mitochondrial cytochrome $b$ gene. Mol Phylogenet Evol 37: 721-732

Keith P, Marquet G, Valade P, Bosc P, Vigneux E (2006) Atlas des poissons et des crustacés d'eau douce des Comores, Mascareignes et Seychelles. Muséum National d'Histoire Naturelle, Paris

Keith P, Hoareau TB, Lord C, Ah-Yane O, Gimonneau G, Robinet T, Valade P (2008) Characterisation of postlarval to juvenile stages, metamorphosis and recruitment of an amphidromous goby, Sicyopterus lagocephalus (Pallas) (Teleostei: Gobiidae: Sicydiinae). Mar Freshw Res 59:876-889

> Leggett WC, Deblois E (1994) Recruitment in marine fishes: Is it regulated by starvation and predation in the egg and larval stages? Neth J Sea Res 32:119-134

> Leis JM (2002) Pacific coral-reef fishes: the implications of behaviour and ecology of larvae for biodiversity and conservation, and a reassessment of the open population paradigm. Environ Biol Fishes 65:199-208

Lord C, Keith P (2008) Threatened fishes of the world. Sicyopterus sarasini Weber \& Beaufort, 1998 (Gobiidae). Environ Biol Fishes 83:169-170

Lord C, Brun C, Hautecoeur M, Keith P (2010) Insights on endemism: comparison of the duration of the marine larval phase estimated by otolith microstructural analysis of three amphidromous Sicyopterus species (Gobioidei: Sicydiinae) from Vanuatu and New Caledonia. Ecol Freshw Fish 19:26-38

Maeda K, Yamasaki N (2007) Size and age at recruitment and spawning season of sleeper, genus Eleotris (Teleostei: Eleotridae) on Okinawa island, southern Japan. Raffles Bull Zool 14:199-207

> Malavoi JR, Souchon Y (2002) Description standardisée des principaux faciès d'écoulement observables en rivière: clé de détermination qualitative et mesures physiques. Bull Fr Peche Piscicult 365-366:357-372

McCormick MI, Molony BW (1995) Influence of water temperature during the larval stage on size, age and body condition of a tropical reef fish at settlement. Mar Ecol Prog Ser 118:59-68

McDowall RM (1988) Diadromy in fishes: migration between freshwater and marine environments. Groom Helm, London

McDowall RM (1997) The evolution of diadromy in fishes (revisited) and its place in phylogenetic analysis. Rev
Fish Biol Fish 7:443-462

McDowall RM (2004) Ancestry and amphidromy in island freshwater faunas. Fish Fish 5:75-85

McDowall RM (2007) On amphidromy, a distinct form of diadromy in aquatic organisms. Fish Fish 8:1-13

McDowall RM (2008) Diadromy, history and ecology: a question of scale. Hydrobiologia 602:5-14

- Meekan MG, Carleton JH, McKinnon AD, Flynn K, Furnas $M$ (2003) What determines the growth of tropical reef fish larvae in the plankton: food or temperature? Mar Ecol Prog Ser 256:193-204

Miller TJ, Crowder LB, Rice JA, Marschall EA (1988) Larval size and recruitment mechanisms in fishes: toward a conceptual framework. Can J Fish Aquat Sci 45:1657-1670

NOAA Coral Reef Watch (2000) NOAA Coral Reef Watch $50 \mathrm{~km}$ satellite virtual station time series data for Reunion Island, 1 Jan 2006-31 Dec 2008. Available at http://coralreefwatch.noaa.gov/satellite/vs/index.html, accessed 1 April 2011

Pouilly M (1994) Relations entre l'habitat physique et les poisons des zones à Cyprinidés rhéophiles dans trois cours d'eau du Bassin Rhodanien: vers une simulation de la capacité d'accueil pour les peuplements. PhD thesis, Claude Bernard University, Lyon

R Development Core Team (2010) R: A language and environment for statistical computing. R Foundation for Statistical Computing, Vienna, www.R-project.org/

> Radtke RL, Kinzie RA III, Folsom SD (1988) Age at recruitment of Hawaiian freshwater gobies. Environ Biol Fishes 23:205-213

Radtke RL, Kinzie RA III, Shafer DJ (2001) Temporal and spatial variation in length of larval life and size at settlement of the Hawaiian amphidromous goby Lentipes concolor. J Fish Biol 59:928-938

> Raventos N, Macpherson E (2005) Effect of pelagic larval growth and size-at-hatching on post-settlement survivorship in two temperate labrid fish of the genus Symphodus. Mar Ecol Prog Ser 285:205-211

Searcy SP, Sponaugle S (2000) Variable larval growth in a coral reef fish. Mar Ecol Prog Ser 206:213-226

Searcy SP, Sponaugle S (2001) Selective mortality during the larval-juvenile transition in two coral reef fishes. Ecology 82:2452-2470

Shen KN, Tzeng WN (2008) Reproductive strategy and recruitment dynamics of amphidromous goby Sicyopterus japonicus as revealed by otolith microstructure. J Fish Biol 73:2497-2512

> Shima JS, Findlay A (2002) Pelagic larval growth rate impacts benthic settlement and survival of a temperate reef fish. Mar Ecol Prog Ser 235:303-309

> Shimizu A, Uchida K, Abe SI, Udagawa M, Sato T, Katsura K (2005) Evidence of multiple spawning in wild amphidromous type ayu. Fish Sci 71:1379-1381

Shimizu A, Uchida K, Udagawa M, Ohkubo M, Ito H, Yamamoto S, Takasawa T (2008) Multiple spawning of amphidromous type ayu Plecoglossus altivelis in a large river, Mogami River System. Fish Sci 74:1283-1289

Sponaugle S (2010) Otolith microstructure reveals ecological and oceanographic processes important to ecosystem-based management. Environ Biol Fishes 89: $221-238$

Sponaugle S, Grorud-Colvert K (2006) Environmental variability, early life-history traits, and survival of new coral reef fish recruits. Integr Comp Biol 46:623-633

Sponaugle S, Pinkard D (2004) Impact of variable pelagic 
environments on natural larval growth and recruitment of the reef fish Thalassoma bifasciatum. J Fish Biol 64:34-54

Sponaugle S, Grorud-Colvert K, Pinkard D (2006) Temperature-mediated variation in early life history traits and recruitment success of the coral reef fish Thalassoma bifasciatum in the Florida Keys. Mar Ecol Prog Ser 308: $1-15$

Taillebois L, Keith P, Valade P, Torres P, Baloche S, Dufoura S, Rousseau K (2011) Involvement of thyroid hormones in the control of larval metamorphosis in Sicyopterus lagocephalus (Teleostei: Gobioidei) at the time of river recruitment. Gen Comp Endocrinol 173:281-288

Tamada K, Iwata K (2005) Intra-specific variations of egg

Editorial responsibility: Christine Paetzold,

Oldendorf/Luhe, Germany size, clutch size and larval survival related to maternal size in amphidromous Rhinogobius goby. Environ Biol Fishes 73:379-389

Valade P, Lord C, Grondin H, Bosc P and others (2009) Early life history and description of larval stages of an amphidromous goby, Sicyopterus lagocephalus (Gobioidei: Sicydiinae). Cybium 33:309-319

Victor BC, Wellington GM (2000) Endemism and the pelagic larval duration of reef fishes in the eastern Pacific Ocean. Mar Ecol Prog Ser 205:241-248

Vigliola L, Meekan MG (2002) Size at hatching and planktonic growth determines post-settlement survivorship of a coral reef fish. Oecologia 131:89-93

Submitted: July 15, 2011; Accepted: February 20, 2012

Proofs received from author(s): May 17, 2012 